\title{
KETERLIBATAN PESERTA DIDIK DALAM PEMBELAJARAN BAHASA INGGRIS MELALUI PROJECT-BASED LANGUAGE LEARNING (PBLL)
}

\author{
Finny Anita ${ }^{1}$, Linda Susilawati ${ }^{2}$ \\ ${ }^{1}$ Program Studi Pendidikan Bahasa Inggris, Fakultas Pendidikan Bahasa dan Seni, \\ IKIP PGRI Pontianak \\ ${ }^{2}$ SMP Negeri 1 Sungai Kakap, Jl. Raya Sungai Kakap \\ ${ }^{1}$ finnyanita@gmail.com
}

\begin{abstract}
Abstrak
Tujuan penelitian ini adalah untuk meningkatkan keterlibatan peserta didik dalam pembelajaran bahasa Inggris melaui model pembelajaran Project-Based Language Learning (PBLL). Desai penelitian yang digunakan adalah Classroom Action Research yang dirancang oleh Craig Mertler. Data penelitian berasal dari angket dan lembar observasi. Data yang dianalisa menghasilkan hanya $19,4 \%$ peserta didik yang terlibat pada dimensi emosional di siklus pertama, dan pada siklus kedua meningkat menjadi $33,3 \%$. Pada dimensi behavioral 13,9\% peserta didik terlibat di siklus pertama dan $27,8 \%$ di siklus kedua. Pada dimensi kognitif 38,9\% peserta didik yang terlibat di siklus pertama dan 52,8\% di siklus kedua. Data observasi perilaku peserta didik menunjukan perilaku keterlibatan yang sangat kurang terhadap pembelajaran di kelas maupun di luar kelas.
\end{abstract}

Kata Kunci: keterlibatan siswa, model pembelajaran, $P B L L$.

\begin{abstract}
The purpose of this study was to increase the students engagement in learning English through the Project-Based Language Learning (PBLL) learning model. The design of the research used was Classroom Action Research designed by Craig Mertler. The research data came from questionnaires and observation sheets. The data analyzed resulted in only 19.4\% of students involved in the emotional dimension in the first cycle, and in the second cycle increased to 33.3\%. In the behavioral dimension $13.9 \%$ of students were involved in the first cycle and $27.8 \%$ in the second cycle. In the cognitive dimension $38.9 \%$ of students were involved in the first cycle and $52.8 \%$ in the second cycle. The data from observation of students' behavior shows very low upon students engagement towards learning in the classroom or outside the classroom.
\end{abstract}

Keywords: students engagement, model of learning, PBLL.

\section{PENDAHULUAN}

Proses penyelenggaraan pembelajaran di sekolah yang sebelumnya menempatkan peserta didik sebagai penerima informasi hanya memposisikan mereka sebagai pelaku pasif. Perkembangan isu pembelajaran di sekolah yang sudah berkembang sangat pesat menggiring proses 
pembelajaran yang mau tidak mau harus menempatkan peserta didik sebagai pelaku yang aktif, karena sejatinya pembelajaran adalah tentang bagaimana peserta didik mendapatkan pengalaman belajarnya. Proses pembelajaran semestinya bukan semata arahan pendidik atau guru, namun pemenuhan kebutuhan pembelajaran peserta didik.

Sekolah-sekolah di Indonesia, dalam penyelenggaraan pendidikannya belum sepenuhnya dapat memberikan pengalaman pembelajaran yang ideal dimana peserta didik yang sepenuhnya mendapat pengalaman langsung dari proses pembelajarannya. Hal ini bukan hanya karena kondisi sekolah dan personel sekolah yang belum dapat sepenuhnya mengembangkan potensi diri dan potensi sekolah yang ada, karena kendala-kendala tertentu, namun salah satunya karena penerapan kurikulum di sekolah tidak dibuat sendiri oleh sekolah, namun merupakan turunan dari kurikulum nasional. Isu ini tentu saja menjadi tantangan tersendiri bagi guru sebagai ujung tombak penggerak perbaikan mutu pendidikan di kelas.

Proses pembelajaran yang dirancang oleh guru di sekolah hendaknya memperhatikan pemenuhan kebutuhan pembelajaran peserta didik. Peserta didik bisa jadi bukannya enggan untuk mengikuti pembelajaran, tapi karena rancangan pembelajaran belum sepenuhnya memuat aktivitas pembelajaran yang dapat melibatkan peserta didik sepenuhnya dalam proses pembelajaran. Keterlibatan peserta didik dalam pembelajaran menjadi penting untuk ditelaah dan harus mendapatkan perhatian penuh oleh guru di sekolah agar pengalaman pembelajaran yang dapat dimanfaatkan dapat sepenuhnya diperoleh peserta didik.

Keterlibatan peserta didik (student engagement) dalam pembelajaran dapat didefinisikan sebagai tingkat perhatian, keingintahuan, minat, optimis, dan gairah yang ditunjukan oleh peserta didik ketika mereka belajar atau diajar, yang dapat berkembang ke tingkatan motivasi bahwa mereka harus belajar dan mengalami kemajuan dalam pendidikan mereka.

"Student engagement is defined as, the degree of attention, curiosity, interest, optimism, and passion that students show when they are learning or being taught, which extends to the level of 
motivation they have to learn and progress in their education. (Hidden Curriculum dalam Nelson, 2016)"

Kondisi ini akhirnya memaksa guru-guru di sekolah untuk dapat mengembangkan kreatifitasnya dalam merancang program pelaksanaan pembelajaran dengan sebaik mungkin, mulai dari merumuskan indikator pencapaian pembelajaran, tujuan pembelajaran, materi pembelajaran, pendekatan dan teknik pembelajaran, metode dan model pembelajaran, media dan sumber belajar, serta hal-hal terkait pembelajaran lainnya.

Model pembelajaran Project-Based Learning sudah diakui melalui penelitian-penelitian dan banyak diusung sebagai salah satu model pembelajaran yang dapat meningkatkan keterlibatan peserta didik dalam proses pembelajaran. Adapun hasil pemikiran para ahli terkait isu tersebut terdapat dalam hasil penelitian yang sudah dipublikasikan oleh; Hittel (2013), Kubik (2015), Miller (2016), Nelson (2016), Salam (2016), dan Quint dan Condliffe (2018).

Berangkat dari gagasan dan hasil kajian yang sangat menarik pada penerapan model pembelajaran Project-Based Learning (PBL) dalam upaya peningkatan keterlibatan peserta didik, maka dipandang penting untuk memberikan perlakuan yang serupa kepada peserta didik di SMP Negeri 1 Sungai Kakap. Penelitian ini merupakan salah satu bagian kegiatan Program Penugasan Dosen di Sekolah (PDS) oleh Kementerian Riset dan Teknologi dan Pendidikan Tinggi (Kemenristekdikti).

Model pembelajaran yang diterapkan adalah Project-Based Language Learning $(P B L L)$ yang merupakan pengembangan dari model pembelajaran Project-Based Learning (PBL) dikarenakan tujuan penelitian ini adalah sebagai upaya untuk meningkatkan keterlibatan peserta didik pada mata pelajaran bahasa Inggris. Pada studi ini peserta didik diarahkan untuk mengalami model PBLL yang dirancang oleh Ibrahim Farouk (2016) dengan materi yang disesuaikan dengan muatan Kurikulum 2013 dan disesuaikan dengan karakteristik peserta didik. 


\section{METODE}

Penelitian ini merupakan penelitian tindakan kelas (classroom action research) yang dengan orientasi pada peningkatan keterlibatan peserta didik sebagai solusi dari kurangnya motivasi belajar peserta didik melalui model pembelajaran Project-Based Language Learning (PBLL). Penelitian dilaksanakan di SMP Negeri 1 Sungai Kakap, Kabupaten Kubu Raya, Provinsi Kalimantan Barat pada peserta didik kelas IX E pada mata pelajaran bahasa Inggris.

Desain penelitian yang digunakan adalah desain penelitian Classroom Action Research yang terdiri dari empat tahap, yaitu: tahap perencanaan (planning), tahap pelaksanaan (implementing), tahap pengamatan (observation), dan tahap refleksi (reflecting) (Mertler, 2014: 42). Tahapan penelitian tindakan kelas ini dapat digambarkan seperti pada Gambar 1. berikut.

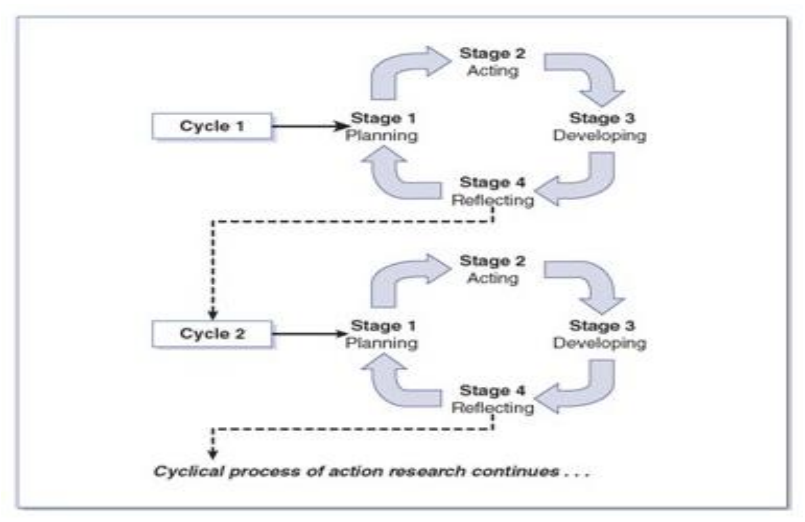

Gambar 1. Bagan Alur Rancangan Penelitian Tindakan Kelas

Pengumpulan data menggunakan data dari angket (questionnaire) dan lembar observasi (observation checklist). Angket digunakan untuk mendapatkan seberapa besar data keterlibatan peserta didik dalam pembelajaran ada di dimensi apa saja; dimensi emosional (emotional dimension), dimensi behavioral (behavioral dimension) atau dimensi kognitif (cognitif dimension), atau tidak ada keterlibatan sama sekali (Nelson, 2016: 30). Angket yang digunakan adalah Classroom Engagement Inventory (CEI) yang diciptakan oleh Wang, Bergin, and Bergin pada the University of Missouri dalam Nelson (2016) yang dimodifikasi dengan menggunakan 2 skala saja Yes dan No. 
Sedangkan lembar observasi digunakan untuk mendapatkan hasil observasi afektif peserta didik selama proses pembelajaran berlangsung guna mengetahui tingkat perubahan tingkah laku peserta didik atas keterlibatannya terhadap pengalaman pembelajaran melalui model pembelajaran Project-Based Language Learning (PBLL).

\section{HASIL DAN PEMBAHASAN}

Hasil yang dicapai dari penelitian ini diperoleh dari dua jenis data, yaitu: data dari lembar observasi (observation sheet) dan data dari angket (questionnaire).

1. Data dari angket

Angket diberikan 2 kali, yaitu pada akhir siklus pertama dan pada akhir siklus kedua untuk mendapatkan data perubahan tingkat keterlibatan peserta didik. Data yang dianalisa menghasilkan hanya $19,4 \%$ peserta didik yang terlibat pada dimensi emosional di siklus pertama, dan pada siklus kedua meningkat menjadi $33,3 \%$. Pada dimensi behavioral 13,9\% peserta didik terlibat di siklus pertama dan $27,8 \%$ di siklus kedua. Pada dimensi kognitif $38,9 \%$ peserta didik yang terlibat di siklus pertama dan $52,8 \%$ di siklus kedua.

2. Data dari lembar observasi

Peserta didik menunjukan tingkatan keterlibatan yang bervariasi selama proses pembelajaran menggunakan $P B L L$ berlangsung. Peserta didik tidak terlalu antusias ketika diberikan arahan penugasan proyek (tahapan $P B L L$ ). Hanya beberapa peserta didik saja yang memperhatikan dengan seksama arahan yang terkait tugas proyek yang harus mereka kerjakan. Peserta didik banyak yang aktif mengerjakan tugas mereka jika guru sedang mengamati. Mereka bekerjasama baik secara berpasangan maupun ketika dalam kelompok. Mereka juga saling berbagi informasi. Sebagian besar peserta didik tidak terlalu peduli dengan tugas yang diberikan ketika guru tidak mengamati langsung. Beberapa dari mereka bahkan mengganggu temannya yang sedang mengerjakan pekerjaannya.

Peserta didik tidak sepenuhnya memanfaatkan pembelajaran di luar kelas untuk mengomunikasikan kemajuan proyek kelompok yang mereka kerjakan dengan menggunakan aplikasi Whatsapp seperti yang sudah direkomendasikan guru. Peserta didik menuntaskan proyek kelompok yang ditugaskan, yaitu membuat 
rekaman video terkait penggunaan teks prosedur dalam kehidupan sehari-hari, namun belum memperhatikan kualitas hasil proyek dengan baik. Peserta didik belum memiliki rasa tanggung jawab yang tinggi atas keterlaksana dan kemajuan hasil proyek kelompok mereka.

Pada saat penyajian hasil penugasan proyek mereka di depan kelas, peserta didik juga belum memperhatikan keterampilan public speaking untuk presentasi. Penggunaan bahasa presentasi yang baik dan benar dan etika ketika menyampaikan presentasi di hadapan peserta didik lainnya (audience).

Hasil dari kedua alat pengumpulan data; angket dan lembar observasi menunjukan bahwa tingkat keterlibatan peserta didik sangat rendah dan perilaku mereka juga menunjukan bahwa mereka tidak antusias mengikuti proses penyelenggaraan pembelajaran baik di dalam kelas maupun di luar kelas. Model pembelajaran yang diterapkan diharapkan dapat membantu peserta didik dalam menyesuaikan waktu dan kecepatan pembelajaran sesuai karakteristik masingmasing peserta didik, nyatanya tidak sesuai dengan tujuan yang ingin dicapai.

Hal ini menjadi catatan penting baik untuk guru, terlebih mestinya untuk peerta didik sendiri untuk dapat menghayati dengan seksama terlaksananya proses pembelajaran yang bermakna bagi peserta didik. Gaya mengajar guru dengan ceramah, mencatat, menerjemahkan dan mengerjakan LKS sepertinya masih disenangi peserta didik dibandingkan dengan $P B L L$ yang seharusnya dapat memberikan manfaat pembelajaran yang lebih baik. Guru harus dapat membantu peserta didik berjuang dalam melibatkan diri sepenuhnya dalam proses pembelajaran mereka dengan menggunakan model pembelajaran yang dapat mengakomodir kebutuhan mereka, walaupun peserta didik mesti bersusah payah dalam membiasakan diri mereka dengan model pembelajaran yang baru.

\section{SIMPULAN}

Model pembelajaran PBLL dapat memberikan pengalaman belajar peserta didik dengan lebih baik jika dilaksanakan dengan langkah-langkah yang tepat. Dukungan dari guru, personel sekolah dan masyarakat akan sangat membantu terlaksananya pengalaman pembelajaran yang sepenuhnya dimiliki peserta didik jika semua pihak berkomitmen dengan baik. Keterlibatan peserta didik dalam 
penyelenggaraan pembelajaran di kelas merupakan komponen yang sangat penting dalam upaya peningkatan mutu pendidikan di sekolah. Peserta didik harus dibantu agar dapat mengembangkan potensi diri dan potensi yang ada di lingkungan sekitarnya untuk peningkatan kualitas kompetensi dan keterampilan mereka. Peserta didik menghadapi tantangan besar di masyarakat jika tidak dibekali dengan pengetahuan, keterampilan dan kemampuan teknologi yang baik yang dapat difasilitasi di sekolah-sekolah.

\section{UCAPAN TERIMA KASIH}

Terima Kasih penulis ucapkan kepada Direktorat Jendral Pembelajaran dan Kemahasiswaan Kementrian Riset, Teknologi, dan Pendidikan Tinggi (Belmawa RISTEKDIKTI) dengan kegiatan Revitalisasi LPTK melalui hibah Penugasan Dosen di Sekolah (PDS) 2018 yang mendanai kegiatan ini. Terimakasih juga kami sampaikan kepada lembaga IKIP PGRI Pontianak yang telah memfasilitasi kegiatan ini.

\section{DAFTAR PUSTAKA}

Farouk, Ibrahim. 2016. “A Project-Based Language Learning Model for Improving the Willingness to Communicate of EFL Students" Proceedings of IMCIC ICSIT 2016

Hittel, Janelle N. 2013. "Hands-on Project Based Learning - The Key to Student Engagement" Vancouver Island University.

Kubik, Timothy. 2015. “Increase Student Engagement Through Project-Based Learning" dalam Best Practices Newsletter tanggal 17 Maret 2015.

Mertler, Craig A. 2014. "Penelitian Tindakan Kelas" Jakarta: PT. Indeks.

Miller, Andrew. 2016. "The Potential of Project Based Learning and English Language Learners" dalam Curriculum in Context.

Nelson, Noelle J. 2016. "Student Engagement and Project-Based Learning in The Social Studies Classroom” Hamline University: DigitalCommons@Hamline

Quint, Janet dan Condliffe, Barbara. 2018. "Project-Based Learning: A Promising Approach to Improving Student Outcomes" MDCR.

Salam, Faridah., Mailok, Ramlah., Ubaidullah, Norhasbiah. dan Ahmad, Umar. 2016. "The Effect of Project-Based Learning against Students' Engagement" 
Jurnal Pendidikan Bahasa, Vol. 7, No. 2, Desember 2018

dalam International Journal of Development Research. Vol. 6, Issue, 02, pp. 6891-6895, February, 2016. 